\title{
Influence of Rind Hardness on Sugarcane Quality
}

\author{
Sujeet Pratap Singh ${ }^{1}$, Amrita Nigam $^{2}$, Ram Kushal Singh ${ }^{{ }^{*}}$ \\ ${ }^{1}$ Centre for Sugarcane Biotechnology, Sugarcane Research Institute, U. P. Council of Sugarcane Research, Shahjahanpur, India; \\ ${ }^{2}$ School of Life Sciences, Indira Gandhi National Open University, New Delhi, India. \\ Email: *rks.upcsr@gmail.com
}

Received June $20^{\text {th }}, 2013$; revised July $20^{\text {th }}, 2013$; accepted August $10^{\text {th }}, 2013$

Copyright (C) 2013 Sujeet Pratap Singh et al. This is an open access article distributed under the Creative Commons Attribution License, which permits unrestricted use, distribution, and reproduction in any medium, provided the original work is properly cited.

\begin{abstract}
Sugar recovery in a factory depends upon regular crushing and quality of varieties besides various other working parameters. Strategies for increased productivity and sugar recovery, varietal improvement can bring out through selection of parents to get maximum gains. These are governed by sugar content, fiber, rind hardness and cane yield. In order to assess the breeding value of different traits including rind hardness, study was undertaken at Sugarcane Research Institute, Shahjahanpur, during 2011-2012. Phenotypic difference and correlations among agronomic characters, basic quality characters and rind hardness in 120 segregating genotypes derived from contrast bi-parental cross (UP9530 $\times$ Co86011) of sugarcane cultivar were studied in this experiment. All the traits observed were found statistically significant among the mapping populations. The mean value of rind hardness was 5.91 with a range from 2.08 to 12.10 among 120 segregating population including their parents. Rind hardness (RHD) showed significant positive genotypic correlation with sugar yield-related traits viz; cane weight $(\mathrm{CW}, \mathrm{r}=0.325)$, cane yield (CYLD, $\mathrm{r}=0.380)$ and sugar yield (SUYLD, $r=0.248)$. Significant negative correlation was observed for rind hardness with commercial cane sugar percent (CCS\%, $\mathrm{r}=-0.388)$, number of millable cane (NMC, $\mathrm{r}=-0.216)$, hand refractometer brix \%-October $(\mathrm{HBR}, \mathrm{r}=-0.154)$, Brix $\%$ in juice (BR, $r=-0.119)$ and Sucrose $\%$ in juice (SUC, $r=-0.080$ ). The simple correlation analysis showed that RHD, CW, CYLD and SUYLD showed significant positive correlation for agronomic characters, but for basic quality characters had negative correlations. Result indicated that rind hardness was found to have economically important trait due to showing significant positive and negative correlation with sugar yield and sugar content, respectively. The study also revealed that with the reduction in rind hardness, sugar recovery may increase. Present findings indicated that the rind hardness could play as a key role in the selection of elite genotypes in breeding program to develop high sugar, high yielding, erect, non-lodging, disease and insect resistant varieties. The details of the study were discussed in the manuscript.
\end{abstract}

Keywords: Rind Hardness; Sugarcane; Genetic Correlation; Sugar Yield-Related Traits

\section{Introduction}

The sugar recovery of a factory in addition to different factors including climate also depends upon consistent working of factory and the quality of variety available for crushing. The quality of varieties depends upon different factors like rind hardness, sucrose percent in juice and purity. The major objective of sugarcane breeder is to increase the sugar yield as well as biomass production, which can be accomplished by either sugar content, fiber or cane yield [1]. Nearly $80 \%$ of sugar produced is from sugarcane while the remaining $20 \%$ is contributed by sugarbeet and palm [2]. Considering the sweetness requirements for growing population day by day, it is necessary to produce high sugar-yielding varieties. Sugar-

"Corresponding author. cane yield is the product of quantitatively inherited phenotypic traits viz; number of millable cane, stalk length, stalk diameter, stalk weight, leaves length, cane yield and rind hardness $[3,4]$

Sugarcane cultivars have close/tight relationship between sugar yield and its yield-related traits. The important traits such as stalk diameter, stalk number, stalk weight, stalk height, brix, fiber and sugar yield among all segregating population have been different significantly for each other and the amount of variability among all progenies has been showing transgressive segregation among them [5]. Fiber content affects significantly biomass, sugar yield and rind hardness. Juice extraction significantly reduces with increasing fiber percent cane and rind hardness [6]. Bio-mass content has been directly associated with rind hardness trait. All sugar-related 
traits viz; leaf area, number of green leaves, internode length, HR brix and sucrose per cent have been significantly correlated with rind hardness, resulting in the development of resistance/tolerance against multiple diseases and pests including dreadful red rot pathogens into the cane stalk [7]. Rind hardness, pith and high fiber content have close association with each other and also low insect (D. saccharalis) damage to sugarcane stalk [8] and negative correlation between internode rind hardness and sugarcane borer incidence exists [9].

Rind hardness is also playing an important role in developing resistance against various abiotic and biotic stresses all over the world in sugarcane. One difficult factor associated with releasing sugarcane borer-resistant cultivars is the positive relationship between resistance and high fiber content. Selection of sugarcane borer-resistant clones increases the frequency of ideotypes with high fiber, pith, tight leaf sheaths and increased rind hardness of imamture internodes [8]. An alternative approach is needed to identify a mechanism of resistance that is less strongly associated with reduced sucrose recovery. Antibiosis, one of the three recognized mechanisms of resistance, is one possibility and is used to describe those adverse effects on the insect's life history that result when an insect uses a host-plant cultivar or species for food. Exploitation of this mechanism will require a different selection strategy than what is currently practiced in breeding program [10].

The correlation between rind hardness with fibre percent cane is more significant and fibre \% cane is significantly associateted with insect (E. saccharina) resistance [11]. Hence, although rind hardness may be a good character for imparting plant resistance, its association with fibre and the well-established negative relationship between fibre \% cane and recoverable sucrose, make it undesirable as a selection trait for resistance to the borer. Although high sucrose yielding varieties have previously been considered as more susceptible to E. saccharina [11, 12].

In breeding program, developing borer tolerant varieties is, however, delayed due to general awareness and lack of the knowledge for disease resistance selection strategies. Resistance and susceptibility are responsible for developing pith in segregating population which contribute significantly to resistance development. Two other factors viz; rind hardness and fiber content, were more closely associated with genotypic resistance than pith. Fiber content was correlated with phenotypic resistance in all cases. Phenotypic selection at early stages may provide good genotypes for lowering insect damage [13].

Sugar yield has been achieved primarily by increasing biomass yield rather than sugar content $[14,15]$. The rind hardness varies with the sugarcane cultivars as well in segregating population. Rind hardness may also be influenced by the growing environmental conditions. The rind hardness of the cane stalk affects the milling efficiency and quality of the cane. Cane harvesting by hand is more complicated due to high rind effects and easier to harvest due to their softness. The sugar-related traits such as brix, sucrose, purity, reducing sugar, as well as rind hardness, rind thickness (softness) and fibre content are the selection criteria for best chewing types in sugarcane [16]

The rind hardness trait has been measured earlier by using the maize rind-penetrometer (pressure required to push a penetrometer needle through the rind) in sugarcane [17]. The rind-hardness was determined from the third and fourth internodes below the youngest apical fully-expanded internode. These internodes are referred to as target internodes as they are sites of insect larval penetration into the stalk $[8,18]$. Meager information is available on the direct and indirect effects of rind hardness traits on sugarcane and sugar productivity. Present findings were reported to evaluate statistically about the relationship between rind hardness traits and sugar yieldrelated traits in segregating population derived from sugarcane commercial cultivars UP9530 $\times$ Co86011.

\section{Material and Method}

Experiment was carried out during 2011-12 at Sugarcane Research Institute (SRI) experimental farm Shahjahanpur (Longitude $79^{\circ} 37^{\prime} \mathrm{E}$ and latitude $27^{\circ} 35^{\prime} \mathrm{N}$ ). The temperature ranged from $7.2^{\circ} \mathrm{C}-21.2^{\circ} \mathrm{C}$ during December, 2011 whereas $6.22^{\circ} \mathrm{C}-17.5^{\circ} \mathrm{C}$ during January 2012 . There were no rainfall during December 2011 but $36.8 \mathrm{~mm}$ rainfall was observed during January 2012. Relative humidity was recorded $75 \%$ (December, 2011) and 76\% (January, 2012). Four rainy days were observed. 226 segregating progenies (genotypes) were derived from a bi-parental cross of UP9530 and Co86011 having contrasting traits for sugar content. The pistil parent UP9530 having the genes for low sugar, high rind hardness and tolerant to water logged conditions. Pollen parent Co86011 having the genes for high sugar, low fiber, low rind hardness along with high yielding ability. Out of 226 segregating genotypes, 120 genotypes were randomly selected for their qualitative and quantitative study. Segregating genotypes were planted in randomized block designs (RBD) with three replications along with their parent. Genotypes were planted in rows at $0.9-\mathrm{m}$ line to line distance and 1.0-m apart between the genotypes. The plot size was $0.9 \times 1.0 \mathrm{~m}^{2}$. Cultural practices and fertilizer applications were provided as per the recommendation at SRI, Shahjahanpur.

Phenotypic data for all the traits were recorded among 120 segregating genotypes. Number of millable cane 
(NMC) was counted for each plot at 360 day after planting (DAP). Stalks were randomly sampled in each plot for each genotype to measure stalk diameter (SD) \& stalk length (SL) at 300 and 360 DAP respectively. Stalk length were observed from the first visible dewlap leaf to the stalk base. SD was recorded at the middle of the internode (one third of the stalk length from the base to the top) by using a vernier caliper. Three stalks from each plot were harvested at 360 DAP and average to record cane weight $(\mathrm{CW})$. Estimated cane yield (CYLD) was recorded by multiplying $\mathrm{NMC}$ and $\mathrm{CW}$. Hand refractometer brix (HBR) was recorded during October by punching in stalk. Sucrose percent juice (SUC), Brix percent juice (BR) (total soluble solids in juice) and purity coefficient (PUR) were analysed as standard procedure of Meade and Chen [19] during December 2011. PUR and CCS percent were calculated by using following formula:

$$
\begin{aligned}
& \mathrm{PUR}=(\mathrm{SUC} / \mathrm{BR}) \times 100 \\
& \mathrm{CCS} \%=[\mathrm{SUC}-(\mathrm{BR}-\mathrm{SUC}) 0.4] \times 0.73
\end{aligned}
$$

Sugar yield ton per hactare (SUYLD) was estimated by multiplying cane yield and commercial cane sugar $(\mathrm{CCS} \%)$. The rind hardness data was recorded by punching mid part of the internode situated at mid region of the stalk. Rind hardness (RHD) was measured for each genotype and average by using rind hardness tester in numerical value as per Ram and Khan [5] at 300 DAP.

Analysis of variance (one way-ANOVA) for rind hardness trait was analysed by statistical software. Correlations coefficients were measured among 12 sugar yieldrelated traits of 120 genotypes by the OPSTAT statistical package [20]. The phenotypic variance and the error variance obtained from the analysis of variance were used to estimate the standard error, $\mathrm{CV}$ and $\mathrm{CD}$ for rind hardness trait as well as all traits.

\section{Result and Discussions}

In this study, a bi-parental cross of UP9530 and Co86011 was affected at Sugarcane Breeding Institute Coimbatore during November 2008 and more than $226 \mathrm{~F}_{1}$ segregating individuals were evaluated for association between quantitative and qualitative traits with rind hardness among randomly selected 120 segregating genotypes. On perusal of the data on thirteen cane and sugar-related traits including rind hardness of 120 segregating genotypes with their parents UP9530 and Co86011 (Table 1), it could be observed that rind hardness being an important trait also shows positive correlations with erectness and non lodging tendency. Comparison on agronomic and quality traits in different segregating genotypes was presented in Table 1 . The results indicated highly significant differences existed among NMC, SL, SD, LL, CW, CYLD HBR, BR, SUC, PUR, CCS\%, SYLD and RHD $(\mathrm{P}<0.05)$ in different segregating genotypes.

Population mean for NMC was 11 which ranged from 1 to 25 per plot in different genotypes. The average $\mathrm{CW}$ was $1.3 \mathrm{Kg}$, ranging from $0.35 \mathrm{Kg}$ to $2.05 \mathrm{Kg}$. Population mean for CYLD, the most desirable traits for growers was recorded $1.03 \mathrm{Kg}$ which ranged from $0.75 \mathrm{~kg}$ to $10.69 \mathrm{~kg}$ per plot with their parents (UP9530 - 9.24 $\mathrm{kg} / \mathrm{plot} \&$ Co86011 - $10.40 \mathrm{~kg} / \mathrm{plot})$. This finding is in agreement with the earlier findings reported by various workers only for yield-related traits viz; number of millable cane, stalk length, stalk diameter and single stalk weight [3,21-23]

The two parents were showing differences in their qualitative and quantitative values along with rind hardness. The significant segregation for rind hardness was observed in all segregating genotypes. The mean and range for all the traits viz; NMC, SL, SD, LL, CW, CYLD, HBR, BR, SUC, PUR, CCS\%, SYLD and RHD were recorded. The traits value had wider ranges among

\begin{tabular}{|c|c|c|c|c|c|c|c|c|c|c|c|c|c|}
\hline \multirow{2}{*}{$\begin{array}{l}\text { Variation in } \\
\text { population }\end{array}$} & \multicolumn{6}{|c|}{ Cane yield-related traits } & \multicolumn{6}{|c|}{ Sugar-related traits } & \multirow{2}{*}{ RHD } \\
\hline & NMC & $\begin{array}{c}\mathrm{SL} \\
(\mathrm{cm})\end{array}$ & $\begin{array}{c}\text { SD } \\
(\mathrm{cm})\end{array}$ & $\begin{array}{c}\text { LL } \\
(\mathbf{c m})\end{array}$ & $\begin{array}{l}\text { CW } \\
\text { (kg) }\end{array}$ & $\begin{array}{c}\text { CYLD } \\
\text { (kg/clu-mp) }\end{array}$ & $\begin{array}{l}\text { HBR \% } \\
\text { (Oct) }\end{array}$ & $\begin{array}{c}\text { BR \% } \\
\text { (Dec) }\end{array}$ & $\begin{array}{l}\text { SUC \% } \\
\text { (Dec) }\end{array}$ & $\begin{array}{c}\text { PUR } \\
(\%)\end{array}$ & CCS (\%) & $\begin{array}{l}\text { SYLD } \\
\text { (T/ha) }\end{array}$ & \\
\hline Mean & 11 & 268.2 & 2.07 & 134.3 & 1.03 & 10.69 & 11.75 & 17.61 & 15.07 & 85.49 & 11.76 & 13.86 & 5.91 \\
\hline Range & $1-25$ & $\begin{array}{c}113- \\
335\end{array}$ & $\begin{array}{c}0.95- \\
2.10\end{array}$ & $\begin{array}{l}96- \\
216\end{array}$ & $\begin{array}{l}0.35- \\
2.05\end{array}$ & $\begin{array}{l}0.75- \\
30.80\end{array}$ & $\begin{array}{l}4.73- \\
20.50\end{array}$ & $\begin{array}{c}10.44- \\
24.04\end{array}$ & $\begin{array}{l}8.50- \\
20.84\end{array}$ & $\begin{array}{l}78.55- \\
90.24\end{array}$ & $\begin{array}{l}6.77- \\
16.16\end{array}$ & $\begin{array}{l}1.08- \\
29.48\end{array}$ & $\begin{array}{c}2.08- \\
12.1\end{array}$ \\
\hline $\operatorname{UP9530}\left(\mathrm{P}_{1}\right)$ & 14 & 280 & 1.86 & 143 & 0.66 & 9.24 & 14.27 & 16.93 & 14.13 & 83.46 & 11.13 & 12.24 & 7.79 \\
\hline $\operatorname{Co86011}\left(\mathrm{P}_{2}\right)$ & 14 & 268 & 2.60 & 116 & 0.74 & 10.36 & 19.00 & 20.14 & 17.63 & 87.54 & 13.6 & 17.61 & 5.75 \\
\hline $\mathrm{CD}$ & 3.96 & 0.161 & 0.33 & 0.145 & 0.27 & 5.191 & 2.065 & 0.29 & 0.24 & 6.12 & 0.50 & 7.47 & 0.712 \\
\hline $\mathrm{SE}(\mathrm{d})$ & 2.01 & 0.09 & 0.17 & 0.074 & 0.13 & 2.633 & 1.047 & 0.15 & 0.12 & 3.10 & 0.25 & 3.79 & 0.361 \\
\hline $\mathrm{SE}(\mathrm{m})$ & 1.42 & 0.05 & 0.12 & 0.052 & 0.09 & 1.862 & 0.741 & 0.11 & 0.09 & 2.20 & 0.18 & 2.68 & 0.256 \\
\hline $\mathrm{CV}$ & 23.46 & 3.73 & 10.23 & 6.727 & 16.19 & 29.951 & 10.90 & 1.04 & 1.00 & 4.46 & 3.01 & 38.76 & 7.531 \\
\hline
\end{tabular}

Table 1. Performance of $120 \mathrm{~F}_{1}$ segregating population derived from UP9530 $\times$ Co86011 for agronomic traits. 
all genotypes along with parents. Thus, the differences among the segregating genotypes were higher than the differences between the parents for all traits, contributing to transgressive segregation among the genotypes (Table 1 \& Figure 1). Accordingly, efforts were made and steps were taken to select the genotype with moderate rind hardness for good sugar recovery in their future. This finding is in agreement with Singh et al. [5,24,25].

The results indicated a highly significant difference existed among 120 segregating genotypes for RHD $(\mathrm{P}<$ 0.01 ). RHD value was ranged from 2.08 (S. 378/08) to 12.10 (S. 26/08) with a mean value 5.91 (Tables 1,2 \& Figure 1). The above observations revealed that difference among segregating genotypes was significantly more than the differences between the parents for RHD. This indicated that transgressive segregation was more pronounced for RHD than other traits (Table 1 \& Figure 1). This may be due to the possibilities of performing contrast family selection for RHD to achieve genetic improvement in quality breeding program. This gave clear indication of selecting better genotypes with moderate RHD value for generating more sugar yielding ability which would be beneficial both for sugar industry and sugarcane growers.

The analysis of variance on the RHD was showed that the mean sum of squares due to genotypes was highly significant at 0.05 and 0.01 probability levels, respectively and $\mathrm{F}$ value was also significant in different segregating genotypes (Table 3). Maximum standard error for RHD was found (SE \pm 0.52) in genotype S. 183/08 whereas the minimum value ( $\mathrm{SE} \pm 0.01$ ) was found in $\mathrm{S}$. 45/08 (Table 2). White et al. [8] also reported significant rind hardness for third internode in plant and ratoon crop.

The data in Table 4 showed that highly significant correlation was found among CW, CYLD, SUYLD, RHD and $\mathrm{CCS} \%(\mathrm{P}<0.01)$. Thus RHD was emphasized due to

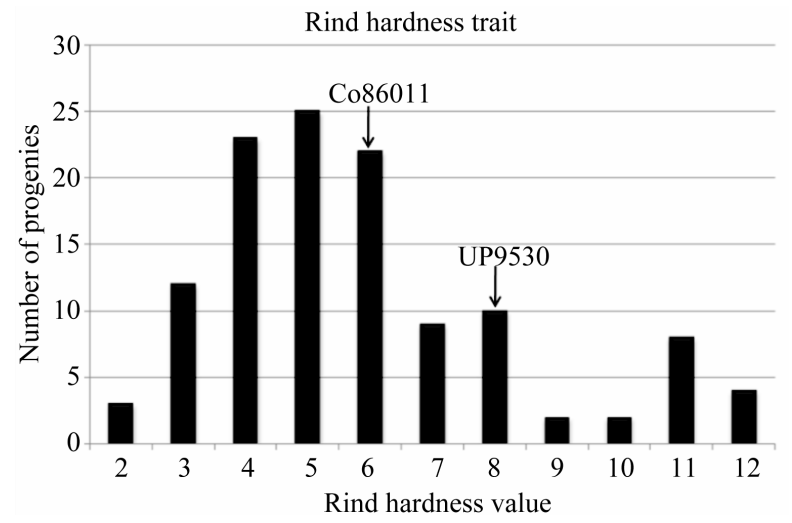

Figure 1. Frequency distribution of rind hardness trait showing transgressive segregation among 120 sugarcane progenies (genotypes) derived from bi-parental crop of UP9530 and Co86011. their significance over all the yield-related and quality traits. CYLD showed highly significant and positive correlation with RHD $(r=0.380)$. Rind hardness were showed significant positive correlation with sugar as well as yield contributed traits viz; CYLD ( $r=0.380)$, SUYLD $(r=0.248)$, SD $(r=0.125)$. Data revealed that RHD had highest significant negative correlation with CCS percent $(r=-0.388)$. Rind hardness had significant negative correlation with NMC $(r=-0.216)$, HBR in October month $(r=-0.154)$, BR $(r=0.119)$ and SUC $(r$ $=-0.080$ ) in the month of December (Tables 4 and 5).

Khan et al. [4] reported that the cane yield was positively correlated with cane girth, weight per stool, sugar yield, tiller numbers and purity $\%$, pol $\%$ and negatively correlated with CCS \%. Ming et al. [25] and Singh et al. [26] also reported that sugar yield was positively correlated with pol, sugar content, stalk number and stalk weight in the segregating population. Number of stalks per stool was a major yield contributing factor followed by height and cane girth as was reported by Singh et al. [27].

The high and significant positive correlation between rind hardness and fibre content was reported by Babu et al. [7]. Fiber content affects both sugar yield and milling efficiency. The extraction of the juice from cane stalk reduces with high fiber and hardness [6]. Sajjadand Khan [28] and Singh et al. [23] reported that fiber was good donor for sugar content and cane yield characters, while the most important character fiber was directly regulated by the rind hardness character $[7,17,29]$. Keeping and Rutherford [11] reported the significant relationship between rind hardness and insect resistance, which was regulated by the fibre $\%$ cane. Hence, the rind hardness character is a good trait for imparting insect resistance [18].

Apart from the above discussions, rind hardness character was showed the other activities in sugarcane crop. Rind hardness and fiber content are highly associated with multiple resistances against diseases and pests. Rind hardness also may be a factor of phenotypic selection in the early stages of variety development for low insect damage $[8,10]$. The other demanding traits namely high sucrose, purity, reducing sugar, rind hardness and fibre content are the choice of selection for best chewing cultivar in sugarcane [16,30].

Hence, RHD was significantly associated with cane and sugar-yield in present findings. This indicates that the rind hardness may be important selection indices for quality breeding program during early selection stage. The use of this trait in selection would allow the identification of potentially superior genotypes and the elimination of undesirable genotypes having more RHD value at early selection stages. Rind hardness trait will also 
Table 2. Mean and standard error of rind hardness among 120 progenies including both parents (UP9530 and Co86011).

\begin{tabular}{|c|c|c|c|c|c|c|c|c|}
\hline \multirow{2}{*}{ Genotypes } & \multicolumn{2}{|c|}{ RHD } & \multirow{2}{*}{ Genotypes } & \multicolumn{2}{|c|}{ RHD } & \multirow{2}{*}{ Genotypes } & \multicolumn{2}{|c|}{ RHD } \\
\hline & Mean & S.E. & & Mean & S.E. & & Mean & S.E. \\
\hline S.17/08 & 5.75 & 0.25 & S.148/08 & 5.03 & 0.02 & S. $140 / 08$ & 3.71 & 0.10 \\
\hline S. $112 / 08$ & 7.89 & 0.20 & S.91/08 & 4.24 & 0.19 & S.401/08 & 11.81 & 0.13 \\
\hline S.45/08 & 5.18 & 0.01 & S. $129 / 08$ & 5.14 & 0.08 & S.17/08 & 3.00 & 0.35 \\
\hline S. $360 / 08$ & 9.15 & 0.23 & S. $432 / 08$ & 6.67 & 0.11 & S.53/08 & 4.57 & 0.19 \\
\hline S.183/08 & 6.15 & 0.52 & S.57/08 & 6.38 & 0.19 & S.127/08 & 6.09 & 0.47 \\
\hline S.56/08 & 4.75 & 0.23 & S.430/08 & 11.04 & 0.40 & S.6/08 & 10.08 & 0.08 \\
\hline S. $374 / 08$ & 6.61 & 0.22 & S.78/08 & 5.83 & 0.14 & S.45/08 & 5.05 & 0.11 \\
\hline S.8/08 & 7.34 & 0.05 & S.36/08 & 3.46 & 0.34 & S. $363 / 08$ & 11.26 & 0.32 \\
\hline S.167/08 & 8.26 & 0.02 & S.206/08 & 3.48 & 0.21 & S.374/08 & 10.99 & 0.06 \\
\hline S.444/08 & 3.78 & 0.11 & S. $15 / 08$ & 5.54 & 0.46 & S.196/08 & 5.16 & 0.08 \\
\hline S. $142 / 08$ & 7.21 & 0.16 & S. $108 / 08$ & 11.00 & 0.47 & S.72/08 & 4.58 & 0.34 \\
\hline S. $118 / 08$ & 7.71 & 0.41 & S. $434 / 08$ & 11.88 & 0.34 & S.64/08 & 3.89 & 0.33 \\
\hline S.163/08 & 4.64 & 0.19 & S.376/08 & 10.93 & 0.36 & S.154/08 & 3.05 & 0.28 \\
\hline S.437/08 & 11.70 & 0.15 & S.375/08 & 5.74 & 0.05 & S.389/08 & 7.64 & 0.02 \\
\hline S. $26 / 08$ & 12.10 & 0.06 & S.80/08 & 10.56 & 0.35 & S.52/08 & 6.81 & 0.30 \\
\hline S.47/08 & 5.25 & 0.70 & S.63/08 & 7.13 & 0.12 & S.357/08 & 8.57 & 0.23 \\
\hline S.136/08 & 5.33 & 0.18 & S.205/08 & 5.92 & 0.34 & S.111/08 & 3.49 & 0.36 \\
\hline S.433/08 & 4.22 & 0.09 & S. $83 / 08$ & 2.79 & 0.34 & S. $31 / 08$ & 3.21 & 0.18 \\
\hline S.445/08 & 3.93 & 0.04 & S.378/08 & 2.08 & 0.47 & S.105/08 & 4.17 & 0.09 \\
\hline S.382/08 & 6.02 & 0.27 & S.95/08 & 4.71 & 0.15 & S.438/08 & 3.30 & 0.29 \\
\hline S.66/08 & 4.82 & 0.12 & S.102/08 & 3.83 & 0.42 & S.185/08 & 3.90 & 0.34 \\
\hline S.84/08 & 8.07 & 0.24 & S.387/08 & 8.26 & 0.32 & S.388/08 & 3.86 & 0.41 \\
\hline S.358/08 & 2.55 & 0.32 & S.414/08 & 10.82 & 0.30 & S.395/08 & 4.09 & 0.03 \\
\hline S.141/08 & 5.88 & 0.36 & S.77/08 & 3.42 & 0.39 & S.54/08 & 5.20 & 0.04 \\
\hline S.390/08 & 5.07 & 0.19 & S. $12 / 08$ & 6.10 & 0.23 & S.356/08 & 3.03 & 0.03 \\
\hline S.39/08 & 6.34 & 0.29 & S.1/08 & 4.69 & 0.43 & S.101/08 & 2.50 & 0.13 \\
\hline S.420/08 & 4.60 & 0.23 & S.169/08 & 5.36 & 0.02 & S.380/08 & 5.95 & 0.15 \\
\hline S.446/08 & 6.29 & 0.17 & S. $160 / 08$ & 4.78 & 0.28 & S.73/08 & 7.05 & 0.30 \\
\hline S. $62 / 08$ & 3.90 & 0.21 & S.90/08 & 3.94 & 0.18 & S.139/08 & 5.85 & 0.15 \\
\hline S.362/08 & 5.07 & 0.04 & S.13/08 & 2.37 & 0.32 & S.173/08 & 8.05 & 0.03 \\
\hline S. $354 / 08$ & 3.78 & 0.34 & S.159/08 & 5.29 & 0.03 & S.351/08 & 6.07 & 0.49 \\
\hline S.208/08 & 6.74 & 0.17 & S.157/08 & 4.86 & 0.09 & S.43/08 & 4.89 & 0.17 \\
\hline S. $452 / 08$ & 7.50 & 0.34 & S.20/08 & 4.12 & 0.02 & S.201/08 & 7.79 & 0.18 \\
\hline S. $450 / 08$ & 3.94 & 0.13 & S.413/08 & 6.10 & 0.08 & S.120/08 & 5.13 & 0.33 \\
\hline S.399/08 & 9.61 & 0.21 & S.133/08 & 4.36 & 0.12 & Co86011 & 5.75 & 0.25 \\
\hline S.355/08 & 3.83 & 0.29 & S. $186 / 08$ & 3.68 & 0.30 & UP9530 & 7.79 & 0.18 \\
\hline S.419/08 & 3.00 & 0.07 & S.96/08 & 11.22 & 0.38 & $\mathrm{CD}$ & 0.712 & \\
\hline S. $175 / 08$ & 5.91 & 0.27 & S.98/08 & 4.49 & 0.25 & $\mathrm{SE}(\mathrm{d})$ & 0.361 & \\
\hline \multirow[t]{2}{*}{ S. $153 / 08$} & 4.41 & 0.14 & S.192/08 & 2.75 & 0.20 & $\mathrm{SE}(\mathrm{m})$ & 0.256 & \\
\hline & & & & & & $\mathrm{CV}$ & 7.531 & \\
\hline
\end{tabular}


Table 3. Analysis of variance among $120 \mathrm{~F}_{1}$ segregating genotypes for rind hardness.

\begin{tabular}{ccccc}
\hline Source of Variation & DF & Sum of Squares & Mean Squares & F-Calculated \\
\hline Replications & 2 & 1.32 & & 17.59 \\
Genotypes & 119 & 2092.62 & 0.2 & $89.78^{* * *}$ \\
Error & 238 & 46.61 & & \\
Total & 359 & 2140.56 & & \\
\hline
\end{tabular}

${ }^{* * *}$ Significant at $0.01 \%$.

Table 4. Correlation coefficients among 120 segregating population for thirteen agronomic traits.

\begin{tabular}{|c|c|c|c|c|c|c|c|c|c|c|c|c|c|}
\hline Traits & NMC & SL & SD & LL & CW & CYLD & HBR (O) & HBR (J) & BR & SUC & CCS\% & SUYLD & RHD \\
\hline NMC & & $0.068^{*}$ & $0.066^{*}$ & $0.109^{*}$ & -0.032 & $0.799^{* *}$ & -0.027 & 0.056 & $-0.086^{*}$ & $-0.072^{*}$ & $-0.068^{*}$ & $0.782^{* *}$ & $-0.216^{* *}$ \\
\hline SL & & & $0.362^{* *}$ & 0.009 & -0.174 & -0.032 & $0.182^{*}$ & 0.052 & $0.085^{*}$ & $0.069^{*}$ & $0.099^{*}$ & 0.008 & 0.059 \\
\hline SD & & & & -0.025 & -0.060 & 0.057 & $0.094^{*}$ & $0.074^{*}$ & $0.146^{*}$ & $0.120^{*}$ & $0.125^{*}$ & $0.090^{*}$ & $0.125^{*}$ \\
\hline LL & & & & & 0.087 & $0.131^{*}$ & $-0.174^{*}$ & $-0.070^{*}$ & $0.084^{*}$ & $0.099^{*}$ & $0.088^{*}$ & $0.141^{*}$ & $0.111^{*}$ \\
\hline CW & & & & & & $0.488^{* *}$ & $-0.196^{*}$ & $-0.086^{*}$ & $-0.064^{*}$ & $-0.073^{*}$ & $-0.087^{*}$ & $0.473^{* *}$ & $0.325^{* *}$ \\
\hline CYLD & & & & & & & $-0.149^{*}$ & -0.023 & $-0.148^{*}$ & $-0.145^{*}$ & $-0.158^{*}$ & $0.953^{* *}$ & $0.380^{* *}$ \\
\hline HBR O) & & & & & & & & $0.665^{* *}$ & 0.049 & 0.019 & 0.032 & $-0.135^{*}$ & $-0.154^{*}$ \\
\hline HBR (J) & & & & & & & & & 0.027 & 0.014 & 0.032 & -0.029 & $-0.162^{*}$ \\
\hline BR & & & & & & & & & & $0.983^{* *}$ & $0.984^{* *}$ & $0.097^{*}$ & $-0.119^{*}$ \\
\hline SUC \% & & & & & & & & & & & $0.989^{* *}$ & $0.404^{* *}$ & -0.080 \\
\hline CCS \% & & & & & & & & & & & & $0.093^{*}$ & $0.388^{* *}$ \\
\hline SUYLD & & & & & & & & & & & & & $0.248^{* *}$ \\
\hline RHD & & & & & & & & & & & & & \\
\hline
\end{tabular}

*Significant at $5 \%,{ }^{* *}$ Significant at $1 \%$.

Table 5. Correlation value of rind hardness with all 12 traits.

\begin{tabular}{clcc}
\hline Sl. No. & Traits & $\begin{array}{c}\text { Correlation value of } \\
\text { rind hardness }\end{array}$ & Statistical Remark \\
\hline 1 & Number of millable cane & $-0.216^{*}$ & $\mathrm{~S}$ \\
2 & Stalk length & 0.059 & $\mathrm{NS}$ \\
3 & Stalk diameter & $0.125^{*}$ & $\mathrm{~S}$ \\
4 & Leaf leangth & $0.111^{*}$ & $\mathrm{~S}$ \\
5 & Per cane weight & $0.325^{* *}$ & $\mathrm{~S}$ \\
6 & Cane yield & $0.380^{* *}$ & $\mathrm{~S}$ \\
7 & Hand refractometer brix \% (October) & $-0.154^{*}$ & $\mathrm{~S}$ \\
8 & Hand refractometer brix \% (January) & $-0.162^{*}$ & $\mathrm{~S}$ \\
9 & Brix \% (December) & $-0.119^{*}$ & $\mathrm{~S}$ \\
10 & Sucrose \% (December) & -0.008 & $\mathrm{~S}$ \\
11 & Commercial cane sugar \% & $0.388^{* *}$ & $\mathrm{~S}$ \\
12 & Sugar yield & $0.248^{* *}$ & $\mathrm{~S}$ \\
\hline
\end{tabular}

${ }^{*}$ Significant at $5 \%,{ }^{* *}$ Significant at $1 \%$.

promote the development of idle genotypes having erect, non-lodging, red rot disease resistance and borer resistance.

\section{REFERENCES}

[1] N. G. I. Bamber, P. A. Jackson and M. Hewitt, "Sucrose Accumulation in Sugarcane Stalks Does Not Limit Photosynthesis and Biomass Production," Crop and Pasture
Science, Vol. 62, No. 10, 2011, pp. 848-858. doi: $10.1071 / \mathrm{CP} 11128$

[2] N. V. Nair, "Sugarcane Agriculture and Sugar IndustryCurrent Scenario and Future Prospect," International Training on Breeding Sugarcane for Sugar-Industrial Complex, Sugarcane Breeding Institute, Coimabtore 1216 October 2009.

[3] A. O. Ahmed, O. Ahmed and D. Basil, "The Influence of 
Characters Association on Behavior of Sugarcane Genotypes (Saccharum Spp) for Cane Yield and Juice Quality," World Journal of Agricultural Sciences, Vol. 6, No. 2, 2010, pp. 207-211.

[4] F. A. Khan, M. YasirIqbal and Md. Sultan, "Morphogenetic Behaviour of Some Agronomic Traits of Sugarcane (Saccharum officinarum L.)," Pakistan Journal Agriculture Science, Vol. 44, No. 4, 2007, pp. 600-603.

[5] M. C. Mancini, L. D. Perecin, M. A. P. Bidoia, M. A. Xavier, M. G. A. Landell and L. R. Pinto, "Characterization of the Genetic Variability of a Sugarcane Commercial Cross through Yield Components and Quality Parameters," Sugar Tech, Vol. 14, No. 2, 2012, pp. 119-125. doi:10.1007/s12355-012-0141-5

[6] D. M. Hogarth and K. W. V. Cross, "The Inheritance of Fiber Content in Sugar Cane," Proceedings of Australian Society Sugar Cane Technology, 1987, pp. 93-98.

[7] C. Babu, Koodalingam, U. S. Natarajan, R. M. Shanthi and P. Govindaraj, "Assessment of Rind Hardness in Sugarcane (Sachharum spp. Hybrids) Genotypes for Development of Non Lodging Erect Canes," Advances in Biological Research, Vol. 3, No. 1-2, 2009, pp. 48-52.

[8] W. H. White, T. L. Tew and E. P. Richard Jr., "Association of Sugarcane Pith, Rind Hardness, and Fiber with Resistance to the Sugarcane Borer," Journal of American Society Sugar Cane Technology, Vol. 26, No. 1, 2006, pp. 87-100.

[9] F. A. Martin, C. A. Richard and S. D. Hensley, "Host Resistance to Diatraea saccharalis (F.): Relationship of Sugarcane Internode Hardness to Larval Damage," Environmental Entomology, Vol. 4, No. 5, 1975, pp. 687-688.

[10] W. H. White, A. L. Hale, J. C. Veremis, T. L. Tew, E. P. Richard, "Registration of Two Sugarcane Germplasm Clones with Antibiosis to the Sugarcane Borer (Lepidoptera: Crambidae.)," Journal of Plant Registrations, Vol. 5, No. 2, 2011, pp. 248-253. doi:10.3198/jpr2010.07.0429crg

[11] M. G. Keeping and R. S. Rutherford, "Resistance Mechanisms of South African Sugarcane to the Stalk Borer Eldana saccharina (Lepidoptera: Pyralidae): A Review," Proceedings of African Sugarcane Technology Association, 2004, pp. 78.

[12] O. L. Kvedaras, M. G. Keeping, F. R. Goebel and M. J. Byrne, "Larval Performance of the Pyralid Borer Eldana saccharina Walker and Stalk Damage in Sugarcane: Influence of Plant Silicon, Cultivar and Feeding Site," International Journal of Pest Management, Vol. 53, No. 3, 2007, pp. 183-194.

[13] K. A. Gravois, S. B. Milligan and F. A. Martin, "The Role of Pith, Tube, and Stalk Density in Determining Sugarcane Sucrose Content and Stalk Weight," Theoretical and Applied Genetics, Vol. 79, No. 2, 1990, pp. 273-277. doi:10.1007/BF00225963

[14] Z. Hongkai, L. Guifu, L. Jiannong and H. Juemin, "Genetic Analysis of Sugarcane Biomass Yield and Its Component Traits Using ADAA Model," Journal of Tropical Agriculture, Vol. 47, No. 1-2, 2009, pp. 70-73.

[15] P. A. Jackson, "Breeding for Improved Sugar Content in Sugarcane," Field Crops Research, Vol. 92, No. 2-3,
2005, pp. 277-290. doi:10.1016/j.fer.2005.01.024

[16] P. Rakkiyappan, K. Chiranjivi Rao and V. Jayamani, "Evaluation of Sugarcane Officinarum Clone for Chewing," Sugar Tech, Vol. 2, No. 3, 2003, pp. 155-160. doi:10.1007/BF02943627

[17] M. S. Kang, O. Sosa and J. D. Miller, "Genetic Variation and Advance for Rind Hardness, Flowering and Sugar Yield in Sugarcane," Field Crops Research, Vol. 23, No. 1990, pp. 69-73.

[18] W. H. White, J. D. Miller, S. B. Milligan, D. M. Burner and B. L. Legendre, "Inheritance of Sugarcane Borer Resistance in Sugarcane Derived from Two Measures of Insect Damage," Crop Science, Vol. 41, No. 6, 2001, pp. 1706-1710. doi: $10.2135 /$ cropsci2001.1706

[19] G. P. Meade and J. C. P. Chen, "Cane Sugar Hand Book (10th) Wiley Inter Science," John Wiley and Sons, New York, 1977, p. 947.

[20] O. P. Sheoran, "Hisar. Statistical Package for Agricultural Scientists (OPSTAT)," CCS HAU. http://www.202.141.47.5/opstat/index.asp

[21] K. S. Aitken, S. Hermann, K. Karno, G. D. Bonnett, L. C. McIntyre and P. A. Jackson, "Control of Yield Related Stalk Traits in Sugarcane," Theoretical and Applied Genetics, Vol. 117, No. 7, 2008, pp. 1191-1203. doi:10.1007/s00122-008-0856-6

[22] L. R. Pinto, A. A. F. Garcia, M. M. Pastina, L. H. M. Teixeira, J. A. Bressiani, E. C. Ulian, M. A. P. Bidoia and A. P. Souza, "Analysis of Genomic and Functional RFLP Derived Markers Associated with Sucrose Content, Fiber and Yield QTLs in a Sugarcane (Saccharum spp.) Commercial Cross," Euphytica, Vol. 172, No. 3, 2010, pp. 313-327. doi:10.1007/s10681-009-9988-2

[23] J. Singh, S. Kumar, P. K Singh and D. K Pandey, "Genetic Divergence in Commercial Hybrids of Sugarcane (Saccharum spp. Hybrids)," Cooperative Sugar, Vol. 35, No. 11, 2004, pp. 861-863.

[24] R. K. Singh, P. Singh, S. P. Singh, T. Mohapatra and S. B. Singh, "Mapping QTLs for Sugar Content and Segregation Analysis in Sugarcane," Sugar Cane International, Vol. 24, No. 1, 2006, pp. 7-13.

[25] R. K. Singh, S. P. Singh, D. K. Tiwari, S. Srivastva, S. B. Singh, M. L. Sharma, R. Singh, T. Mohapatra and N. K. Singh, "Genetic Mapping and QTL Analysis for Sugar Yield-Related Traits in Sugarcane," Euphytica, Vol. 191, No. 3. 2013, pp. 333-353. doi:10.1007/s10681-012-0841-7

[26] R. Ming, Y. W. Wang, X. Draye, P. H. Moore, J. E. Irvine and A. H. Paterson, "Molecular Dissection of Complex Traits in Autopolyploids: Mapping QTLs Affecting Sugar Yield and Related Traits in Sugarcane," Theoretical and Applied Genetics, Vol. 105, No. 2-3, 2002, pp. 332-345. doi:10.1007/s00122-001-0861-5

[27] R. K. Singh, S. P. Singh and S. B. Singh "Correlation and Path Analysis in Sugarcane Ratoon," Sugar Tech, Vol. 7, No. 4, 2005, pp. 176-178. doi:10.1007/BF02950610

[28] Md. Sajjad and F. A. Khan, "Genetic Diversity among Sugarcane Cultivars in Pakistan," American-Eurasian Journal Agricultural \& Environmental Science, Vol. 6, 
No. 6, 2009, pp. 730-736.

[29] B. Ram and A. Q. Khan, "Combining Ability Analysis for Yield Characteristics in Sugarcane (Saccharum sp. Complex)," Indian Journal of Genetics and Plant Breeding, Vol. 53, No. 1, 1993, pp. 14-20.

\section{Abbreviations}

NMC: Number of millable cane;

SL: Stalk length;

SD: Stalk diameter;

LL: Leaf length;

CW: Per cane weight;

CYLD: Cane yield;

HBR (O): Hand refractometer Brix\% (October);

HBR (J): Hand refractometer brix\% (January);
[30] R. B. Doule and N. Balasundaram, "Genetic Variability in Fibre and Related Characters for Selection of Sugarcane," Sugar Tech, Vol. 6, No. 1-2, 2004, pp. 73-75. doi:10.1007/BF02942622

BR: Brix\% (December);

SUC: Sucrose\% (December);

PUR: Purity\% (December);

CCS\%: Commercial cane sugar\%;

SUYLD: Sugar yield;

RHD: Rind hardness;

DAP: Day after planting;

S: Statistically significant;

NS: Statistically non-significant. 